\title{
Plant Population Influences Yield Variability of Cabbage
}

\author{
Peter J. Stoffella' and Mike F. Fleming ${ }^{2}$ \\ Agricultural Research and Education Center, IFAS, University of Florida, P. O. Box 248, Fort \\ Pierce, FL 34954
}

Additional index words. Brassica oleracea (Capitata Group), plant density, plant spacing, quality, within-row spacing

\begin{abstract}
Cabbage [Brassica oleracea L. (Capitata Group) cv. Bravo] transplants were grown on raised beds at Fort Pierce, Fla., during Fall 1987 and 1988. Plants were spaced at 8, 15, 23, 30, and $38 \mathrm{~cm}$ within rows or populations equivalent to $123,000,61,500,41,000,30,800$, and 24,600 plants/ha. Individual root weights, total plant weights, and core length increased linearly as within-row spacing (WRS) increased in both experiments. Untrimmed head weights, trimmed head weights, head height, head width, and core width increased quadratically as WRS increased in both experiments. Head shape and core index did not differ among WRS in either experiment, except for a quadratic increase in the head height : bead width ratio (head shape) as WRS increased in the 1988 experiment. Coefficients of variability (CV) for most measured variables decreased as WRS increased, indicating a reduction in plant-to-plant variation. Optimum marketable cabbage head size ( >1 kg) and lower plant-to-plant variation $(\mathrm{cv}<20 \%)$ were obtained at WRS of $23 \mathrm{~cm}$ or wider. However, trimmed cabbage yields decreased linearly as WRS increased in both experiments. In this study, a lower plant population (WRS $\geq 23 \mathrm{~cm}$ ) was more conducive to a once-over cabbage harvest since plant-to-plant variation in head size and other yield and quality characteristics was reduced.
\end{abstract}

Fresh-market cabbage is generally harvested manually with the use of harvesting aids. The number of harvests for freshmarket cabbage is influenced by the cultivar selected, environmental conditions, uniformity of head size at time of harvest, and economic climate of the season. A cabbage field with minimal head size variability at time of harvest would reduce the number of harvests. A single harvest would be of economic advantage to cabbage growers, since harvesting costs are a major expense in producing a marketable crop.

Cabbage head development and maturity had generally been variable within and between commercial fields, forcing growers to use multiple harvests. Uniform plant stands, plant spacings, and production and management practices can contribute to a variability reduction in cabbage plant growth, development, and ultimately head size. Marketable yields per hectare, for a onceover harvest, should be higher from fields with uniform cabbage head size at time of harvest.

Plant spacings for a double-row, raised-bed planting system recommended in Florida are 38 to $61 \mathrm{~cm}$ between rows, 25 to $30 \mathrm{~cm}$ between plants in a row, and 1 to $1.5 \mathrm{~m}$ between bed centers (Hochmuth, 1988). Generally, use of low plant populations has increased cabbage head size but reduced marketable yields per hectare (Csizinsky and Schuster, 1985; Knavel and Herron, 1981; White and Forbes, 1976). Halsey et al. (1966) reported a larger cabbage head size but no significant differences in total marketable yields as WRS increased from 23 to $38 \mathrm{~cm}$. We found no past investigations addressing variability in cabbage head size or yield as affected by plant population dynamics. We therefore measured variability in cabbage head size, yields, and quality characteristics when grown at several plant populations.

Received for publication 15 Dec. 1989. Agricultural Experiment Station Journal Series no. R-00328. The cost of publishing this paper was defrayed in part by the payment of page charges. Under postal regulations, this paper therefore must be hereby marked advertisement solely to indicate this fact.

'Associate Professor of Vegetable Crops.

${ }^{2}$ Biological Scientist H.

\section{Materials and Methods}

The experiments were conducted at the Agricultural Research and Education Center, Fort Pierce, during Fall 1987 and 1988. The soil type was a Oldsmar fine sand (sandy, siliceous, hyperthermic Alfic Arenic Haplaquods). Raised beds $\approx 1.1 \mathrm{~m}$ wide and $0.15 \mathrm{~m}$ high were spaced $2.1 \mathrm{~m}$ apart center to center. A 94N-62P-195K fertilizer (kg.ha-l) was applied under a 0.25 m-wide strip of black plastic mulch placed in the center of each bed. This strip-mulch technique, developed by Hayslip (1979), was used to reduce fertilizer leaching from heavy rainfall that is generally expected throughout the growing season.

Transplants of 'Bravo' cabbage, 4 or 5 weeks old, were planted on 29 Oct. 1987 and 8 Nov. 1988, respectively. Transplants were placed in two rows, $0.51 \mathrm{~m}$ apart, per bed. WRS were 8 , $15,23,30$, and $38 \mathrm{~cm}$, which were equivalent to 123,000 , $61,500,41,000,30,800$, and 24,600 plants/ha, respectively. Each plot consisted of 50 plants.

Subsurface irrigation was used throughout the experiment to maintain the water table $\approx 38 \mathrm{~cm}$ below the soil surface. Weeds were controlled manually within the beds and with spray applications of paraquat $\left(6.6 \mathrm{ml} \cdot\right.$ liter $\left.^{-1}\right)$ between beds. Insects and foliar pathogens were chemically controlled as required during crop growth.

Each plot was harvested once when the majority of the cabbage heads reached maturity (initiation of the first head splitting). The mean numbers of days from planting to harvest were $147,145,138,120$, and 112 in the 1987 experiment and 161, $148,136,124$, and 101 in the 1988 experiment for plots with $8,15,23,30$, and $38 \mathrm{~cm}$ WRS, respectively. Each plot was harvested at different times so that cabbage plants could attain their ultimate maturity, regardless of plant population. At harvest, 15 plants from the center of each plot were individually excavated by hand using a modified root-clump excavation technique (Bohm, 1979). The sandy nature of the soil allowed the majority of the root system to remain intact. Roots were severed from the shoots, washed, and fresh weights recorded. Individual untrimmed heads (heads with wrapper leaves) were weighed, then trimmed (trimmed heads) and reweighed. Each head was

Abbreviation: WRS, within-row spacing. 
Table 1. ANOVA (percent sum of squares) for several growth, quality, and yield components of cabbage.

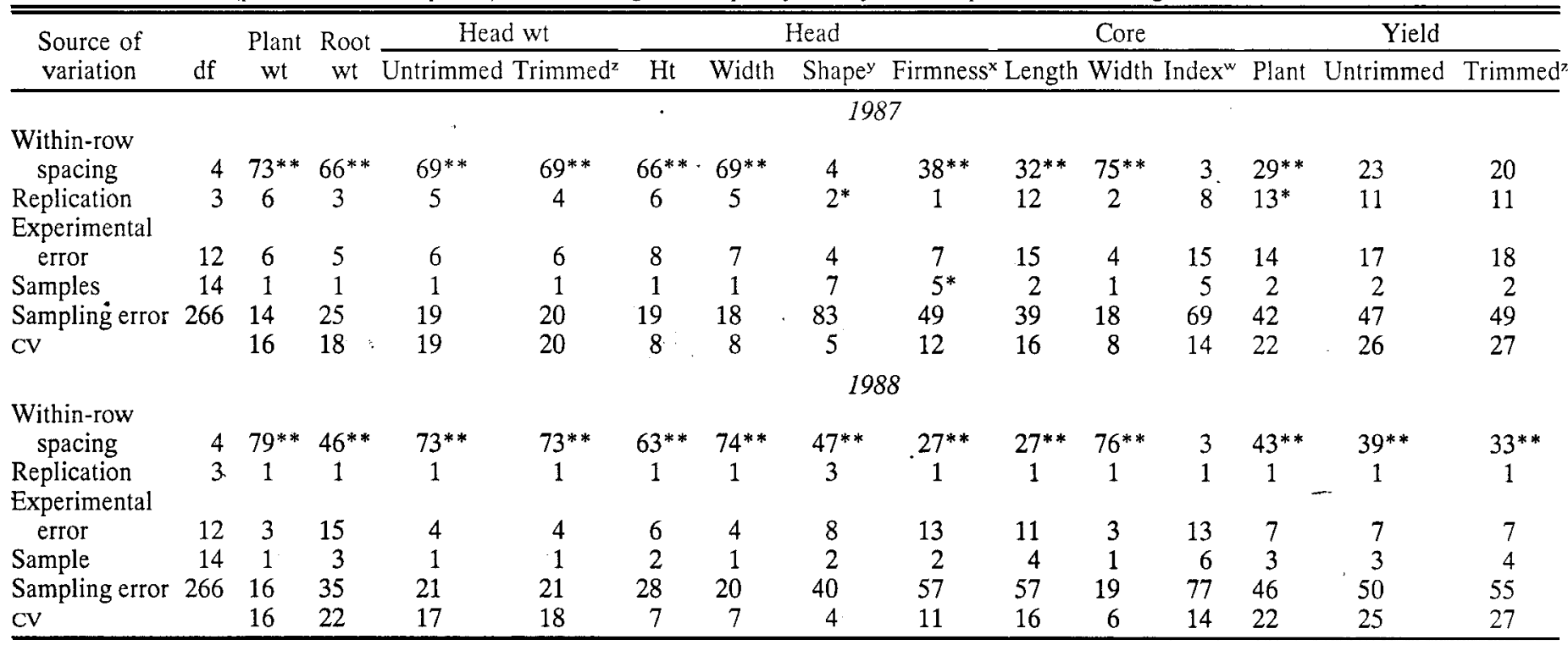

${ }^{\mathrm{z}}$ Trimmed head weight $=$ untrimmed head weight - wrapper leaves weight.

${ }^{\mathrm{y}}$ Head shape $=$ head height/head width.

${ }^{x}$ Head firmness was subjectively rated on a scale of 1 (least compact) to 5 (most compact).

"Core index $=$ core length/head height.

$*, * *$ Significant at $P=0.05$ or 0.01 , respectively.

Table 2. Cabbage' plant, root, and head weights and variability as influenced by WRS.

\begin{tabular}{|c|c|c|c|c|c|c|c|c|}
\hline \multirow{3}{*}{$\begin{array}{l}\text { WRS } \\
(\mathrm{cm})\end{array}$} & \multicolumn{8}{|c|}{ Fresh $w^{z}{ }^{z}$} \\
\hline & \multicolumn{2}{|c|}{ Plant } & \multicolumn{2}{|c|}{ Root } & \multicolumn{2}{|c|}{$\begin{array}{c}\text { Untrimmed } \\
\text { head }\end{array}$} & \multicolumn{2}{|c|}{$\begin{array}{c}\text { Trimmed } \\
\text { head }\end{array}$} \\
\hline & $\mathrm{kg}$ & $C V^{x}$ & $\mathrm{~g}$ & $\mathrm{CV}$ & $\mathrm{kg}$ & $\mathrm{CV}$ & $\mathrm{kg}$ & $\mathrm{CV}$ \\
\hline & \multicolumn{8}{|c|}{1987} \\
\hline 8 & 0.77 & 28.8 & 14.8 & 25.0 & 0.52 & 38.3 & 0.45 & 41.8 \\
\hline 15 & 1.45 & 19.4 & 21.9 & 18.6 & 1.10 & 21.2 & 0.99 & 22.0 \\
\hline 23 & 1.71 & 15.7 & 23.8 & 16.3 & 1.29 & 17.7 & 1.18 & 18.6 \\
\hline 30 & 2.19 & 13.1 & 30.5 & 13.5 & 1.59 & 15.2 & 1.45 & 15.6 \\
\hline 38 & 2.49 & 13.2 & 35.3 & 16.6 & 1.71 & 17.4 & 1.54 & 15.5 \\
\hline \multirow[t]{2}{*}{ Significance $^{w}$} & $L^{*}$ & $\mathrm{Q}^{*}$ & $\mathrm{~L}^{*}$ & $\mathrm{~L}^{*}$ & $\mathrm{Q}^{* *}$ & $\mathrm{Q}^{* *}$ & $\mathrm{Q}^{* *}$ & $\mathrm{Q}^{* *}$ \\
\hline & \multicolumn{8}{|c|}{1988} \\
\hline 8 & 1.10 & 28.7 & 14.4 & 24.9 & 0.83 & 34.4 & 0.72 & 37.4 \\
\hline 15 & 1.81 & 18.2 & 18.8 & 19.3 & 1.44 & 20.3 & 1.29 & 21.2 \\
\hline 23 & 2.36 & 17.2 & 24.5 & 23.7 & 1.87 & 19.1 & 1.69 & 19.7 \\
\hline 30 & 2.77 & 10.9 & 26.3 & 17.9 & 2.10 & 11.6 & 1.91 & 11.9 \\
\hline 38 & 3.23 & 11.0 & 29.4 & 16.2 & 2.31 & 11.8 & 2.10 & 12.1 \\
\hline Significance ${ }^{w}$ & $\mathrm{~L}^{* *}$ & $\mathrm{~L}^{* *}$ & $\mathrm{~L}^{* *}$ & NS & $\mathrm{Q}^{* *}$ & $\mathrm{Q}^{*}$ & $\mathrm{Q}^{* *}$ & $\mathrm{Q}^{* *}$ \\
\hline
\end{tabular}

${ }^{2}$ Data are means of individual plants or heads.

${ }^{y}$ Trimmed head weight $=$ untrimmed head weight - wrapper leaves weight.

${ }^{\mathrm{x}} \mathrm{CV}=$ coefficient of variability.

whinear (L), quadratic (Q), and significant at $P=0.05\left({ }^{*}\right), 0.01\left({ }^{* *}\right)$, or nonsignificant (NS).

dissected vertically, after which head height, head width, core length, and core width were measured. Internal head firmness was subjectively rated on a scale of 1 (least compact) to 5 (most compact). Head shape was calculated as head height/head width. Core index was calculated as core length/head height. Total plant, untrimmed head, and trimmed head weights were calculated on a hectare basis for each plot.

A randomized complete-block design was used, with each WRS treatment replicated four times. Coefficient of variability (cv) was calculated for each plot and used as a measure of plant-to-plant variation. Analysis of variance (ANOVA) was performed on each measured variable and the associated $\mathrm{cv}$ values. Sums of squares (percent of total) were calculated for each source of variation within the ANOVA for each measured variable (Table 1). Linear, quadratic, and cubic orthogonal contrasts were partitioned from the main effect of WRS.

\section{Results and Discussion}

Coefficient of variability values for all variables measured ranged from $5 \%$ to $27 \%$ in 1987 and from $4 \%$ to $27 \%$ in 1988 
Table 3. Cabbage head quality characteristics and variability as influenced by WRS.

\begin{tabular}{|c|c|c|c|c|c|c|c|c|c|c|c|c|c|c|}
\hline \multirow{3}{*}{$\begin{array}{l}\text { WRS } \\
(\mathrm{cm})\end{array}$} & \multicolumn{8}{|c|}{ Head } & \multicolumn{6}{|c|}{ Core } \\
\hline & \multicolumn{2}{|c|}{$\mathrm{Ht}$} & \multicolumn{2}{|c|}{ Width } & \multicolumn{2}{|c|}{ Shape $^{z}$} & \multicolumn{2}{|c|}{ Firmness ${ }^{y}$} & \multicolumn{2}{|c|}{ Length } & \multicolumn{2}{|c|}{ Width } & \multicolumn{2}{|c|}{ Index ${ }^{x}$} \\
\hline & $\mathrm{cm}$ & $\mathrm{CV}^{\mathrm{w}}$ & $\mathrm{cm}$ & $\mathrm{CV}$ & $\mathrm{cm}$ & CV & $\mathrm{cm}$ & $\mathrm{CV}$ & $\mathrm{cm}$ & $\mathrm{CV}$ & $\mathrm{cm}$ & $\mathrm{CV}$ & $\mathrm{cm}$ & $\mathrm{CV}$ \\
\hline \multicolumn{15}{|c|}{1987} \\
\hline 8 & 9.6 & 13.8 & 10.6 & 14.5 & 0.97 & 4.6 & 3.5 & 24.0 & 4.8 & 20.8 & 2.3 & 10.5 & 0.49 & 16.1 \\
\hline 15 & 12.7 & 7.8 & 13.1 & 7.2 & 0.97 & 5.4 & 4.4 & 11.6 & 5.8 & 18.6 & 3.0 & 8.4 & 0.46 & 16.4 \\
\hline 23 & 13.4 & 6.9 & 13.9 & 6.7 & 0.96 & 4.1 & 4.5 & 11.2 & 6.4 & 14.8 & 3.1 & 7.0 & 0.48 & 11.3 \\
\hline 30 & 14.5 & 5.5 & 15.0 & 6.1 & 0.97 & 4.4 & 4.8 & 9.1 & 7.1 & 12.1 & 3.5 & 6.3 & 0.49 & 10.6 \\
\hline 38 & $\cdot 14.6$ & 6.2 & 15.4 & 5.4 & 0.95 & 5.1 & 4.9. & 5.7 & 7.1 & 14.9 & 3.6 & 5.9 & 0.40 & 12.3 \\
\hline $\begin{array}{l}\text { Signifi- } \\
\text { cance }^{w}\end{array}$ & $\mathrm{Q}^{*}$ & $\mathrm{Q}^{* *}$ & $\mathrm{Q}^{* *}$ & $C^{*}$ & NS & NS & $\mathrm{Q}^{* *}$ & $\mathrm{~L}^{* *}$ & $\mathrm{~L}^{*}$ & $\mathrm{~L}^{* *}$ & $\mathrm{Q}^{* *}$ & $\mathrm{~L}^{* *}$ & NS & $\mathrm{L}^{*}$ \\
\hline $\begin{array}{r}8 \\
15 \\
23 \\
30 \\
38\end{array}$ & $\begin{array}{l}12.1 \\
13.9 \\
14.8 \\
15.3 \\
15.8\end{array}$ & $\begin{array}{r}10.9 \\
6.8 \\
6.1 \\
4.2 \\
4.1\end{array}$ & $\begin{array}{l}12.3 \\
15.3 \\
16.8 \\
17.4 \\
18.0\end{array}$ & $\begin{array}{r}13.1 \\
6.8 \\
7.1 \\
4.6 \\
4.4\end{array}$ & $\begin{array}{l}0.98 \\
0.91 \\
0.88 \\
0.88 \\
0.87\end{array}$ & $\begin{array}{l}15 \\
5.6 \\
3.8 \\
4.0 \\
3.7 \\
3.3\end{array}$ & $\begin{array}{l}3.8 \\
4.3 \\
4.1 \\
4.6 \\
4.6\end{array}$ & $\begin{array}{r}17.2 \\
9.8 \\
9.3 \\
9.9 \\
9.0\end{array}$ & $\begin{array}{l}6.7 \\
7.8 \\
8.8 \\
8.5 \\
9.1\end{array}$ & $\begin{array}{r}24.8 \\
18.8 \\
13.8 \\
12.0 \\
9.5\end{array}$ & $\begin{array}{l}2.7 \\
3.2 \\
3.5 \\
3.7 \\
3.9\end{array}$ & $\begin{array}{r}10.0 \\
6.8 \\
6.8 \\
4.4 \\
5.2\end{array}$ & $\begin{array}{l}0.56 \\
0.56 \\
0.59 \\
0.58 \\
0.58\end{array}$ & $\begin{array}{r}20.9 \\
16.3 \\
12.1 \\
10.9 \\
8.6\end{array}$ \\
\hline $\begin{array}{l}\text { Signifi- } \\
\text { cance }^{\text {w }}\end{array}$ & $\mathrm{Q}^{* *}$ & $Q^{*}$ & $\mathrm{Q}^{* *}$ & $Q^{* *}$ & $\mathrm{Q}^{* *}$ & $\mathrm{~L}^{* *}$ & $L^{*}$ & $\mathrm{Q}^{*}$ & $\mathrm{~L}^{* *}$ & $\mathrm{~L}^{*}$ & $Q^{* *}$ & $\mathrm{Q}^{* *}$ & NS & $\mathrm{L}^{*}$ \\
\hline
\end{tabular}

${ }^{2}$ Head shape $=$ head width/head height.

y Head firmness was subjectively rated on a scale of 1 (least compact) to 5 (most compact).

${ }^{x}$ Core index $=$ core length/head height.

wLinear (L), quadratic (Q), cubic (C) and significant at $P=0.05\left({ }^{*}\right), 0.01\left(^{* *}\right)$, or nonsignificant (NS).

Table 4. Cabbage yields/ha as influenced by WRS.

\begin{tabular}{|c|c|c|c|}
\hline \multirow[b]{2}{*}{$\begin{array}{l}\text { WRS } \\
(\mathrm{cm})\end{array}$} & \multicolumn{3}{|c|}{ Yields $\left(\mathrm{t} \cdot \mathrm{ha}^{-1}\right)$} \\
\hline & Plant & $\begin{array}{l}\text { Untrimmed } \\
\text { head }\end{array}$ & $\begin{array}{c}\text { Trimmed } \\
\text { head }^{y}\end{array}$ \\
\hline \multicolumn{4}{|c|}{1987} \\
\hline 8 & 95.2 & 63.9 & 52.2 \\
\hline 15 & 89.3 & 67.3 & 60.8 \\
\hline 23 & 70.2 & 53.0 & 48.4 \\
\hline 30 & 67.2 & 48.8 & 44.5 \\
\hline $38 \ldots$ & 61.3 & 42.0 & 37.9 \\
\hline Significance ${ }^{\mathbf{x}}$ & $\mathrm{L}^{* *}$ & $\mathrm{~L}^{*}$ & $\mathrm{~L}^{*}$ \\
\hline \multicolumn{4}{|c|}{$\cdot 1988$} \\
\hline 8 & 135.1 & 102.2 & 88.7 \\
\hline 15 & 111.5 & 88.6 & 79.6 \\
\hline 23 & 96.7 & 76.7 & 69.3 \\
\hline 30 & 85.1 & 64.4 & 58.7 \\
\hline 38 & 79.4 & 51.7 & 51.7 \\
\hline Significance ${ }^{x}$ & $\mathrm{~L}^{* *}$ & $\mathrm{~L}^{* *}$ & $\mathrm{~L}^{*}$ \\
\hline
\end{tabular}

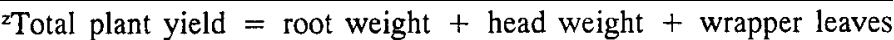
weight.

yTrimmed head yield $=$ head weight - wrapper leaves weight.

${ }^{x}$ Linear $(\mathrm{L})$ and significant at $P=0.05\left(^{*}\right)$ and $=0.01\left(^{* *}\right)$.

(Table 1). Most of the variation (percent sums of squares) was attributed to the main effect of WRS or sampling error. The large sampling error sums of squares for most variables indicates a large plant-to-plant variation occurred in both experiments. Main effects of replication, samples, and the experimental error accounted for $<1470,8 \%$, and $19 \%$, respectively, of the total experimental variation for each variable in both experiments (Table 1).

Individual cabbage plants and root weights increased linearly as WRS increased in both experiments (Table 2). Individual untrimmed and trimmed cabbage head weights increased quadratically as WRS increased in both experiments (Table 2). Larger individual cabbage heads from lower plant populations were previously reported by Csizinszky and Schuster (1985), Halsey
(1966), Knavel and Herron (1981), and White and Forbes (1976). Over $60 \%$ of the experimental variation was associated with WRS for root, plant, untrimmed head, or trimmed head weights in both experiments, except for root weight in the 1988 experiment (Table 1). As roots, plants, and heads increased in weight at wider WRS, cv values generally decreased linearly or quadratically, with the exception of root weight in the 1988 experiment (Table 2). The reduced plant-to-plant variation for root, plant, and head weights as WRS increased may have resulted from the decreased plant competition for light, nutrients, or water at wider WRS.

Cabbage head height, width, and firmness increased and their associated cv values decreased linearly or quadratically as WRS increased (Table 3). However, cv values were only higher than $12 \%$ for head height, width, and firmness when grown at the 8-cm WRS in either experiment. Head shape (ratio of head height to width) is optimum at 1.0. Head shape did not differ among WRS in the 1987 experiment and the ratio decreased quadratically as WRS increased in the 1988 experiment. However, cv values were $<6.0 \%$ for head shape at each WRS in both experiments. The small $(<12 \%) \mathrm{cv}$ values at each WRS (except $8 \mathrm{~cm}$ ) suggest that, while means for cabbage head characteristics are influenced by changing plant populations, the plant-to-plant variation remains minimal.

Cabbage core length and width increased linearly or quadratically, respectively, as WRS increased in both experiments, while cv values decreased (Table 3). Core length was more variable than core width, regardless of plant population. Core index (core length/head height) was not significantly affected by WRS in either experiment (Table 3 ) since $<4 \%$ of the sums of squares were attributed to the main effects of WRS (Table $1)$.

Total plant weight, untrimmed head yield, and trimmed head yield per hectare decreased linearly as WRS increased in both experiments (Table 4). Cabbage heads that are $1 \mathrm{~kg}$ or larger are considered suitable for fresh market (Federal Register, 1977). Mean cabbage trimmed head weight was $<1.0 \mathrm{~kg}$ for cabbage 
grown at 8-cm WRS in both experiments and at 15-cm WRS in the 1987 experiment (Table 2). Mean cabbage trimmed head weight had cv values $>20 \%$ for the 8 - or $15-\mathrm{cm}$ WRS in both experiments (Table 2). Optimum cabbage yields, head size, and head quality characteristics with reduced plant-to-plant variability were achieved with plants grown at WRS wider than 15 $\mathrm{cm}$. The reduced plant-to-plant variation for most cabbage yield and quality characteristics when grown at lower plant populations (WRS $\geq 23 \mathrm{~cm}$ ) would be suited for a once-over harvest. Further experimentation is needed to determine the influence of other cultural and management practices on variability of cabbage growth, yield, and quality characteristics. Reducing plantto-plant variability within a commercial cabbage field may result in a lower number of harvests and ultimately higher economic returns.

The quadratic increase of cabbage head height, head width, and mean head weight, the reduced cv values for these variables, and the linear decrease in trimmed head yield per hectare with wider WRS suggest that the optimum WRS may be in the range of 23 to $30 \mathrm{~cm}$ for a double-row system.

\section{Literature Cited}

Bohm, W. 1979. Methods of studying root systems. Ecological Studies: C. 33. Springer-Verlag, New York.

Csizinszky, A.A. and D.J. Schuster. 1985. Response of cabbage to insecticide schedule, plant spacing, and fertilizer rates. J. Amer. Soc. Hort. Sci. 110:888-893.

Federal Register. 1977. United States standards for grades of cabbage. 42 FR 32541.

Halsey, L. H., J.F. Beeman, D.R. Hensel, W.W. Deen, and V.L. Guzman. 1966. Influence of variety and spacing on yield of cabbage from a single harvest. Proc. Fla. State Hort. Soc. 79:194-201.

Hayslip, N.C. 1979. How to apply strip mulch over banded fertilizer to reduce leaching. Ft. Pierce AREC Research Rept. RL-1979-4, Univ. of Florida.

Hochmuth, G.J. (cd.). 1988. Cabbage production guide for Florida. Univ. Fla. Coop. Ext. Serv. Circ. 117E.

Knavel, D.E. and J.W. Herron. 1981. Influence of tillage system, plant spacing, and nitrogen on head weight, yield, and nutrient concentration in cabbage. J. Amer. Sot. Hort. Sci. 106:540-545.

White, J.M. and R.B. Forbes. 1976. Effect of spacing and fertilizer rates on cabbage yield and head weight. Proc. Fla. State Hort. Soc. 89:118-120. 